\title{
Study of yeast and sugar in bio-energy generation
}

\author{
Teng Howe Cheng ${ }^{1}$, B. C. Kok ${ }^{2}$, C. Uttraphan ${ }^{3}$, M. H. Yee \\ ${ }^{1,2}$ Department of Electrical Power Engineering, Universiti Tun Hussein Onn Malaysia, Malaysia \\ ${ }^{3}$ Department of Computer Engineering, Universiti Tun Hussein Onn Malaysia, Malaysia \\ ${ }^{4}$ Department of Engineering Education, Universiti Tun Hussein Onn Malaysia, Malaysia
}

\begin{tabular}{l} 
Article Info \\
\hline Article history: \\
Received Oct 23, 2019 \\
Revised Dec 30, 2019 \\
Accepted Jan 31, 2020 \\
\hline
\end{tabular}

\section{Keywords:}

Bioelectricity

Biomass

Electrochemical energy

Ethanol fermentation

Microbial fuel cell

Renewable energy

\begin{abstract}
This paper demonstrates a simple and cost-effective bio-energy generation through biochemical reaction between yeast and sugar. Correlation of energy released between baker yeast Saccharomyces cerevisiae concentration and sugar solution concentration can be observed significantly over laboratory works. A certain number of electrons is released during the process of ethanol fermentation, in which sugars are broken down into ethanol and carbon dioxide. Consequently, bio-energy can be captured via two copper rods during the fermentation period from different concentration variables using the principle of microbial fuel cell (MFC). In this case, yeast and sugar have been selected as the concentration variables. The experiment works concluded that higher concentration of sugar solution correlates to the increment of energy output. However, the concentration of sugar beyond $0.6 \mathrm{~g} / \mathrm{ml}$ causes instability of the energy output. At the same time, another considerable limiting factor of the energy output is the area of separation membrane. The overabundance of sugar concentration can lead to adverse effects in harvesting the bio-energy.
\end{abstract}

This is an open access article under the CC BY-SA license.

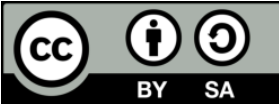

\section{Corresponding Author:}

Teng Howe Cheng,

Department of Electrical Power Engineering,

Universiti Tun Hussein Onn Malaysia,

Parit Raja, 86400 Batu Pahat, Johor, Malaysia.

Email: ge170107@siswa.uthm.edu.my

\section{INTRODUCTION}

Baker yeast Saccharomyces cerevisiae [1] is one of the popular experimental models for microbiology and biochemistry for decades [2-4]. Chemical products by this microbial fermentation potentially allow new polymer synthesis, cost reduction in manufacture and conceivable use of renewable feedstocks [5]. These single-celled eukaryotic fungi are most familiar as the active part in bread making. It is known that Saccharomyces cerevisiae swiftly alters sugars to ethanol and carbon dioxide, $\mathrm{CO}_{2}$. These gases trapped by gluten in bread making which causes the loaf to rise [6-8].

During growth, yeast cells utilize the substrates to acquire essential energy in two ways: glycolysis and respiration. Glycolysis involves the conversion of one molecule of sucrose into two molecules of pyruvate with two molecules of ATP. Pyruvate can be expelled from yeast after decarboxylation to ethanol. Degradation of sugar [9-12], ethanol fermentation [13-16], also termed alcoholic fermentation. It can be happened in both anaerobic and aerobic conditions, with the presence or absence of oxygen, indirectly produces energy due to metabolism [17]. Ethanol produced from the fermentation can contribute to energy generation [18]. During the fermentation period, disassociation of substrate [19] by the enzymic activity will produce energy which usually being overlooked. Therefore, the aim of this paper is to perform an analytical 
assessment on the potential of yeast to become an alternative energy source while providing theoretical principles on how energy was generated.

\section{METHODOLOGY}

The experiment used Saccharomyces cerevisiae yeast as the core of the Microbial Fuel Cell (MFC) [20-22]. Simultaneous conduction of the five bio-energy fuel cell experiment is to determine the electrical output based on the concentration of yeast and sugar. The experiment is setup by following the step-by-step processes as illustrated in Figure 1 and end product as depicted in Figure 2.

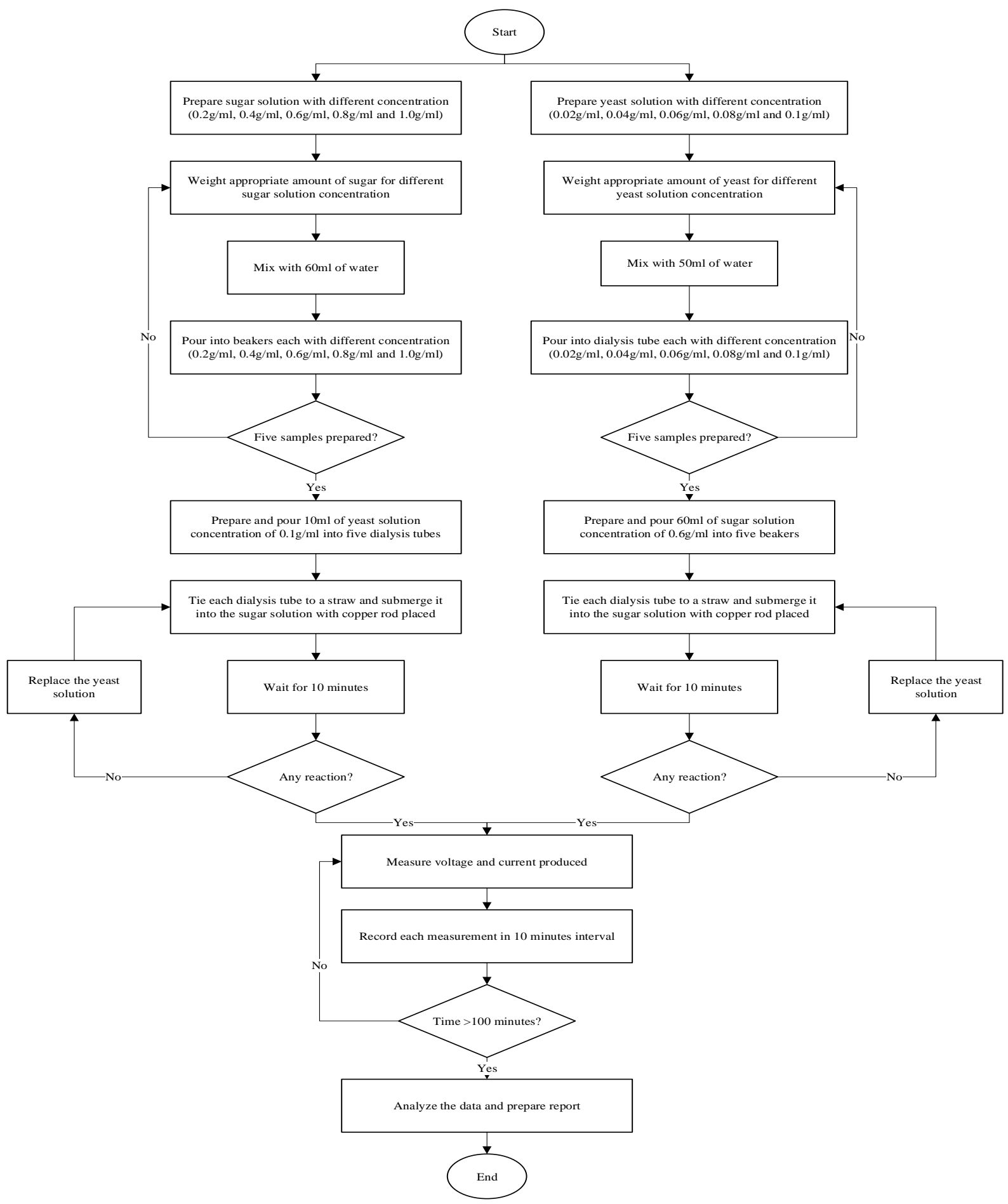

Figure 1. Experimental method flowchart 


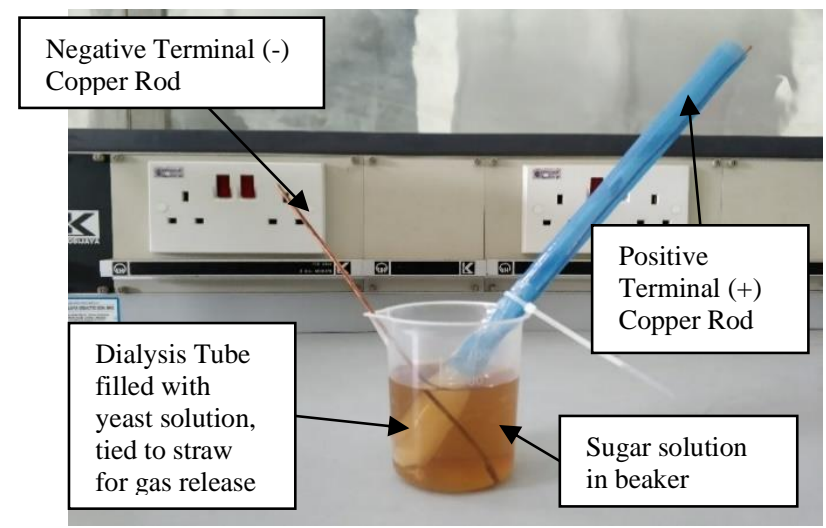

Figure 2.Experiment setup of yeast bio-energy fuel cell

\subsection{Sugar concentration experiment design}

In this experiment, five dialysis tubes $(2.54 \mathrm{~cm} \mathrm{x} 6 \mathrm{~cm})$ is used, each contains yeast solution with constant volume and concentration of $10 \mathrm{ml}$ and $0.1 \mathrm{~g} / \mathrm{ml}$ respectively, while $60 \mathrm{ml}$ of sugar solution concentration varies in $0.2 \mathrm{~g} / \mathrm{ml}, 0.4 \mathrm{~g} / \mathrm{ml}, 0.6 \mathrm{~g} / \mathrm{ml}, 0.8 \mathrm{~g} / \mathrm{ml}$ and $1 \mathrm{~g} / \mathrm{ml}$ in five beakers as shown in Table 1 , in which the purpose is to test the changes of energy emitted due to the changes in sugar concentration. Dialysis tube containing yeast solution is tied together with drinking straw in order to release the carbon dioxide and ethanol produced during the reaction. Two copper rods served as the terminal are placed in both yeast solution and sugar solution. Then the sample is kept rest for 1 hour in room temperature of $26-28^{\circ} \mathrm{C}$ for stabilization before the first measuring is taken.

Table 1. Sugar concentration proportion

\begin{tabular}{ccc}
\hline Beakers & Sugar amount $(\mathrm{g})$ & Sugar solution concentration $(\mathrm{g} / \mathrm{ml})$ \\
\hline 1 & 12 & 0.2 \\
2 & 24 & 0.4 \\
3 & 36 & 0.6 \\
4 & 48 & 0.8 \\
5 & 60 & 1.0 \\
\hline
\end{tabular}

\subsection{Maintaining the integrity of the specifications}

Differs from the previously done experiments, this test is to determine the concentration of yeast that affects the output energy with a similar experimental setup. Yeast is mixed in $50 \mathrm{ml}$ of water to regulate its concentration. Each solution has a constant volume as the preceding experiment. Sugar solution remains constant at $0.6 \mathrm{~g} / \mathrm{ml}$ concentration whereas yeast varies in $0.02 \mathrm{~g} / \mathrm{ml}, 0.04 \mathrm{~g} / \mathrm{ml}, 0.06 \mathrm{~g} / \mathrm{ml}, 0.08 \mathrm{~g} / \mathrm{ml}$ and $0.1 \mathrm{~g} / \mathrm{ml}$ as shown in Table 2 .

Table 2. Yeast concentration proportion

\begin{tabular}{ccc}
\hline Beakers & Yeast amount $(\mathrm{g})$ & Yeast solution concentration $(\mathrm{g} / \mathrm{ml})$ \\
\hline 1 & 1 & 0.02 \\
2 & 2 & 0.04 \\
3 & 3 & 0.06 \\
4 & 4 & 0.08 \\
5 & 5 & 0.10 \\
\hline
\end{tabular}

\section{RESULTS}

Implementing membrane between yeast solution and sugar solution can force the reaction through a bridge, where the energy is harvested. Hence, it is hypothesized that the more concentrated sugar and yeast amount, the more energy can be produced.

\subsection{Sugar and yeast concentration outcome}

Voltage and current are taken every ten minutes from each sample for each experiment which is tabulated in Table 3 and Table 4. 
Table 3. Measurement of voltage and current with different sugar concentrations

\begin{tabular}{cccccccccccc}
\hline Beaker & \multicolumn{2}{c}{1} & \multicolumn{2}{c}{2} & \multicolumn{2}{c}{3} & \multicolumn{2}{c}{4} \\
\hline Concentration $(\mathrm{g} / \mathrm{ml})$ & & 0.2 & & 0.4 & & 0.6 & & 0.8 & \multicolumn{2}{c}{5} \\
\hline Time $(\mathrm{min})$ & $\mathrm{mV}$ & $\mu \mathrm{A}$ & $\mathrm{mV}$ & $\mu \mathrm{A}$ & $\mathrm{mV}$ & $\mu \mathrm{A}$ & $\mathrm{mV}$ & $\mu \mathrm{A}$ & $\mathrm{mV}$ & $\mu \mathrm{A}$ \\
\hline 10 & 24.7 & 5.1 & 114.5 & 4.8 & 139.2 & 5.0 & 143.5 & 5.5 & 117.3 & 5.7 \\
20 & 31.1 & 4.0 & 145.8 & 4.0 & 142.9 & 4.7 & 157.5 & 5.0 & 111.6 & 5.6 \\
30 & 15.5 & 4.0 & 166.4 & 4.6 & 141.1 & 4.5 & 154.6 & 4.7 & 78.2 & 4.9 \\
40 & 25.5 & 5.0 & 148.2 & 3.5 & 152.5 & 4.6 & 141.0 & 4.3 & 116.4 & 5.1 \\
50 & 22.0 & 3.9 & 155.1 & 4.5 & 155.5 & 4.8 & 133.1 & 4.0 & 96.8 & 5.5 \\
60 & 22.3 & 3.7 & 136.3 & 3.4 & 160.1 & 4.4 & 133.7 & 3.7 & 93.8 & 5.4 \\
70 & 19.3 & 3.5 & 142.4 & 3.8 & 158.2 & 4.7 & 128.9 & 3.9 & 92.1 & 5.3 \\
80 & 21.2 & 4.0 & 145.7 & 4.0 & 157.5 & 4.3 & 131.2 & 3.5 & 88.7 & 5.7 \\
90 & 24.6 & 3.6 & 145.2 & 3.9 & 159.3 & 4.5 & 127.4 & 3.3 & 89.5 & 5.5 \\
100 & 18.1 & 3.3 & 137.5 & 3.8 & 154.8 & 4.5 & 125.3 & 3.2 & 85.9 & 5.1 \\
\hline
\end{tabular}

Table 4. Measurement of voltage and current with different yeast concentrations

\begin{tabular}{ccccccccccc}
\hline Beaker & \multicolumn{2}{c}{1} & \multicolumn{2}{c}{2} & \multicolumn{2}{c}{3} & \multicolumn{2}{c}{4} \\
\hline Concentration $(\mathrm{g} / \mathrm{ml})$ & \multicolumn{2}{c}{0.02} & \multicolumn{2}{c}{0.04} & \multicolumn{2}{c}{0.06} & \multicolumn{2}{c}{0.08} & \multicolumn{2}{c}{0.1} \\
\hline Time $(\mathrm{min})$ & $\mathrm{mV}$ & $\mu \mathrm{A}$ & $\mathrm{mV}$ & $\mu \mathrm{A}$ & $\mathrm{mV}$ & $\mu \mathrm{A}$ & $\mathrm{mV}$ & $\mu \mathrm{A}$ & $\mathrm{mV}$ & $\mu \mathrm{A}$ \\
\hline 10 & 7.3 & 4.5 & 35.1 & 3.8 & 136.6 & 3.8 & 137.4 & 4.8 & 147.9 & 4.3 \\
20 & 8.0 & 4.2 & 134.8 & 3.6 & 136.4 & 3.7 & 138.0 & 4.6 & 150.4 & 4.1 \\
30 & 68.5 & 4.0 & 134.3 & 3.4 & 136.3 & 3.7 & 138.6 & 4.3 & 151.4 & 4.0 \\
40 & 68.9 & 3.8 & 133.5 & 3.3 & 136.0 & 3.6 & 139.2 & 4.2 & 151.9 & 4.0 \\
50 & 69.4 & 3.6 & 132.6 & 3.2 & 135.9 & 3.5 & 140.3 & 4.1 & 152.8 & 3.9 \\
60 & 70.1 & 3.1 & 132.4 & 3.0 & 135.8 & 3.5 & 140.9 & 3.9 & 153.3 & 3.6 \\
70 & 70.6 & 3.2 & 132.2 & 3.0 & 135.8 & 3.6 & 141.7 & 3.6 & 154.0 & 3.6 \\
80 & 71.2 & 3.0 & 131.9 & 2.9 & 136.0 & 3.5 & 142.1 & 3.5 & 154.8 & 3.4 \\
90 & 71.6 & 2.9 & 132.0 & 2.9 & 135.9 & 3.3 & 143.4 & 3.1 & 155.1 & 3.2 \\
100 & 71.7 & 2.6 & 131.5 & 2.8 & 137.9 & 2.9 & 144.5 & 3.0 & 154.7 & 3.1 \\
\hline
\end{tabular}

\subsection{Calculated energy output}

In order to determine the energy output from the sample, power (P) is calculated using (1), and energy is then calculated using (2) which is tabulated in Table 5 and Table 6 using cumulative frequency table method.

$$
P=V \times I
$$

where $P$ is power in watt $(\mathrm{W}), V$ is voltage $(\mathrm{V})$ measured from the sample, and $I$ is the current (A) measured from the samples.

$$
E=P \times t
$$

where $E$ is energy in joule $(\mathrm{J})$ and $t$ is time in second (s) which is assumed 1 sec as it is an instantaneous measurement.

Energy generation from the sugar concentration experiment as the numerical results given in Table 5 is plotted as in Figure 3. Beaker 3 has demonstrated steady energy output for $0.6 \mathrm{~g} / \mathrm{ml}$ sugar concentration. Hence, it is chosen to test the yeast concentration since it is the most stable with moderate deviations and able to maintain the energy output. Figure 4 describes the energy generation from yeast concentration experiment as tabulated in Table 6 . The energy generation from $0.1 \mathrm{~g} / \mathrm{ml}$ yeast concentration matches part of the hypothesis made earlier in this section.

Table 5. Cumulative energy generation of each beaker with different sugar concentration

\begin{tabular}{cccccc}
\hline Beaker & 1 & 2 & 3 & 4 & 0.8 \\
\hline Concentration $(\mathrm{g} / \mathrm{ml})$ & 0.2 & 0.4 & 0.6 & 5 & 1.0 \\
\hline Time $(\mathrm{min})$ & Energy $(\mathrm{nJ})$ & Energy $(\mathrm{nJ})$ & Energy $(\mathrm{nJ})$ & Energy $(\mathrm{nJ})$ & Energy $(\mathrm{nJ})$ \\
\hline 10 & 125.97 & 549.6 & 696 & 789.25 & 668.61 \\
20 & 250.37 & 1132.8 & 1367.63 & 1576.75 & 1293.57 \\
30 & 312.37 & 1898.24 & 2002.58 & 2303.37 & 1676.75 \\
40 & 439.87 & 2416.94 & 2704.08 & 2909.67 & 2270.39 \\
50 & 525.67 & 3114.89 & 3450.48 & 3442.07 & 2802.79 \\
60 & 608.18 & 3578.31 & 4154.92 & 3936.76 & 3309.31 \\
70 & 675.73 & 4119.43 & 4898.46 & 4439.47 & 3797.44 \\
80 & 760.53 & 4702.23 & 5575.71 & 4898.67 & 4303.03 \\
10 & 849.09 & 5268.51 & 6292.56 & 5319.09 & 4795.28 \\
\end{tabular}

Bulletin of Electr Eng \& Inf, Vol. 9, No. 2, April 2020 : $443-451$ 


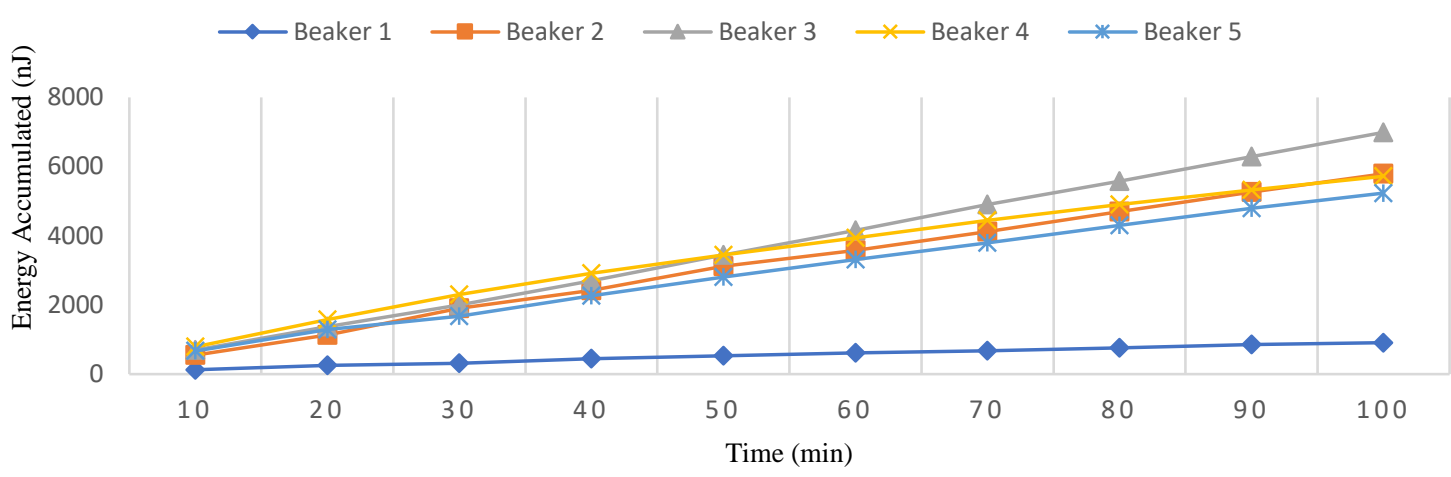

Figure 3. Cumulative frequency plot in sugar concentration experiment

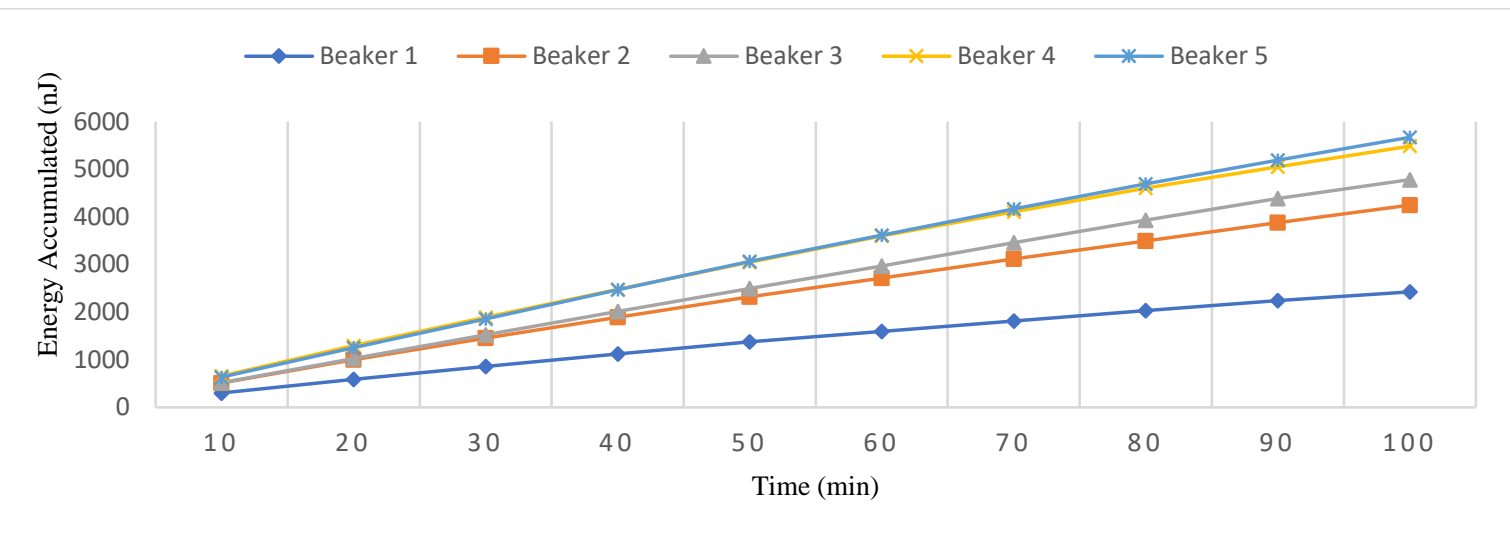

Figure 4. Cumulative frequency plot in yeast concentration experiment

Table 6. Cumulative energy generation of each beaker with different yeast concentration

\begin{tabular}{|c|c|c|c|c|c|}
\hline Beaker & 1 & 2 & 3 & 4 & 5 \\
\hline Concentration $(\mathrm{g} / \mathrm{ml})$ & 0.2 & 0.4 & 0.6 & 0.8 & 1.0 \\
\hline Time $(\min )$ & Energy (nJ) & Energy $(\mathrm{nJ})$ & Energy $(\mathrm{nJ})$ & Energy (nJ) & Energy $(\mathrm{nJ})$ \\
\hline 10 & 302.85 & 513.38 & 519.08 & 659.52 & 635.97 \\
\hline 20 & 588.45 & 998.66 & 1023.76 & 1294.32 & 1252.61 \\
\hline 30 & 862.45 & 1455.28 & 1528.07 & 1890.3 & 1858.21 \\
\hline 40 & 1124.27 & 1895.83 & 2017.67 & 2474.94 & 2465.81 \\
\hline 50 & 1374.11 & 2320.15 & 2493.32 & 3050.17 & 3061.73 \\
\hline 60 & 1591.42 & 2717.35 & 2968.62 & 3599.68 & 3613.61 \\
\hline 70 & 1817.34 & 3113.95 & 3457.5 & 4109.8 & 4168.01 \\
\hline 80 & 2030.94 & 3496.46 & 3933.5 & 4607.15 & 4694.33 \\
\hline 90 & 2238.58 & 3879.26 & 4381.97 & 5051.69 & 5190.65 \\
\hline 100 & 2425 & 4247.46 & 4781.88 & 5485.19 & 5670.22 \\
\hline
\end{tabular}

\section{DISCUSSION}

\subsection{Conversion of sugar to energy}

Fermentation of yeast in sugar water will produce ethanol and carbon dioxide as a byproduct. In the chemical formula, sugar is known as sucrose [23], which contains twelve carbon atoms, twenty two hydrogen atoms, and eleven oxygen atoms. In order to convert sucrose to glucose, water is mixed which glycosidic linkage will be cleaved by invertase to form two moles of glucose [24]as given in (3).

$$
\mathrm{C}_{12} \mathrm{H}_{22} \mathrm{O}_{11}+\mathrm{H}_{2} \mathrm{O} \rightarrow 2 \mathrm{C}_{6} \mathrm{H}_{12} \mathrm{O}_{6}
$$

Hence, once alcoholic fermentation is taken place, one mole of glucose will be converted into two moles of ethanol and two moles of carbon dioxide via yeast reaction as shown in (4). 


$$
\mathrm{C}_{6} \mathrm{H}_{12} \mathrm{O}_{6} \underset{\text { yeast }}{\longrightarrow} 2 \mathrm{C}_{2} \mathrm{H}_{5} \mathrm{OH}+2 \mathrm{CO}_{2}
$$

During the fermentation period, the glucose molecule is broken down into two pyruvate molecules and two water molecules known as glycolysis, (5).

$$
\mathrm{C}_{6} \mathrm{H}_{12} \mathrm{O}_{6}+2 \mathrm{ADP}+2 \mathrm{Pi}+2 \mathrm{NAD}^{+} \rightarrow 2 \mathrm{CH}_{3} \mathrm{COCOO}^{-}+2 \mathrm{ATP}+2 \mathrm{NADH}+2 \mathrm{H}_{2} \mathrm{O}+2 \mathrm{H}^{+}+2 e^{-}
$$

$2 \mathrm{CH}_{3} \mathrm{COCOO}^{-}$is pyruvate, and $\mathrm{Pi}$ is inorganic phosphate. Ethanol and carbon dioxide [25] is converted from pyruvate in the following (6) and (7):

$$
\begin{aligned}
& 2 \mathrm{CH}_{3} \mathrm{COCOO}^{-}+\mathrm{H}^{+} \rightarrow \mathrm{CH}_{3} \mathrm{CHO}+\mathrm{CO}_{2} \\
& \mathrm{CH}_{3} \mathrm{CHO}+\mathrm{NADH}+\mathrm{H}^{+} \rightarrow \mathrm{C}_{2} \mathrm{H}_{5} \mathrm{OH}+\mathrm{NAD}^{+}
\end{aligned}
$$

As shown by the reaction equation, glycolysis causes the reduction of two molecules of nicotinamide adenine dinucleotide $\left(\mathrm{NAD}^{+}\right)$to reduced form as NADH [26]. Two (adenosine diphosphate) ADP molecules are also converted to two ATP and two water molecules viasubstrate-level phosphorylation.

\subsection{Yeast energy reduction over time}

Molar mass of sucrose is $342.2965 \mathrm{~g} / \mathrm{mol}$, whereas one mole always has the same number of objects which is $6.022 \times 10^{23}$. Hence, one molecule of sucrose is described as (8):

$$
\begin{aligned}
& \operatorname{moles}\left(\frac{\text { grams }}{\text { mole }}\right)=\text { grams } \\
& \frac{(342 \mathrm{~g} / \mathrm{mol})}{\left(6.022 \times 10^{23} \text { molecules } / \mathrm{mol}\right)}=5.68 \times 10^{-22} \mathrm{~g} / \text { molecule }
\end{aligned}
$$

One gram of sugar contains:

$$
\frac{1 \mathrm{~g}}{5.68 \times 10^{-22} \mathrm{~g} / \text { molecule }}=1.76 \times 10^{21} \text { molecule }
$$

As a result, two electrons will be produced from one molecule of sucrose during the fermentation period due to the oxidation of the hydrogen atom. Therefore, $3.52 \times 10^{21}$ electrons will be released from one gram of sugar. Electrical charges $(Q)$ is then calculated with the unit Coulomb $(C)$ which contains $6.242 \times 10^{18}$ electrons per $C$ determined by (10).

$$
\begin{aligned}
& Q_{(C)}=Q_{(e)} \times 1.602 \times 10^{-19}[\text { Electron Charge }] \\
& \therefore Q_{(C)}=563.9 C_{[\text {from } 1 \mathrm{~g} \text { of sugar }]}
\end{aligned}
$$

Electric charge, $Q_{(C)}$ is then calculated from maximum value as recorded in the testing of $0.02 \mathrm{~g} / \mathrm{ml}$ yeast concentration (Table 4) using (12). Time taken $(t)$ is assumed $1 \mathrm{sec}$. as it is an instantaneous measurement.

$$
\begin{aligned}
& E=P \times t=V Q_{(C)} \\
& E=302.85 n J=(67.3 m V) Q_{(C)[0.02 g / m l \text { concentration }]} \\
& \therefore Q_{(C)}=\frac{302.85 n J}{67.3 m V}=4.5 \mu C
\end{aligned}
$$


Minimum electric charge, $Q_{(C)}$ is then calculated by using (12) from minimum value as recorded in the testing of $0.02 \mathrm{~g} / \mathrm{ml}$ yeast concentration as shown in Table 4 .

$$
\begin{aligned}
& E=186.42 n J=(71.7 m V) Q_{(C)} \\
& \therefore Q_{(C)}=\frac{186.42 n J}{71.7 m V}=2.6 \mu C
\end{aligned}
$$

From the energy output recorded, it was observed that yeast sugar synthesizing rate drops from $4.5 \mu \mathrm{C}(10 \mathrm{~min})$ to $2.6 \mu \mathrm{C}(100 \mathrm{~min})$, in which the energy output occasionally drops due to the yeast activity which is arbitrary. It is highly dependent on the yeast concentration and surface area of separation membrane $\left(2.54 \mathrm{~cm} \times 3 \mathrm{~cm} \times 2\right.$ sides $\left.=15.24 \mathrm{~cm}^{2}\right)$ which contacts both solutions together. Increasing the concentration of the yeast can leads to the higher output of energy but limited by the constant surface area of the membrane [27]. Hence, the energy output of the yeast MFC is limited. In order to break this limitation, a wider surface area of the membrane is recommended as for more reaction to be occurred.

\section{CONCLUSION}

This study presents the bio-energy yield produced by Saccharomyces cerevisiae. There are several factors that affect the energy generation of plants, including temperature, moisture, soil $\mathrm{pH}$, electrode types, and environment properties. Overview, the yeast MFC energy harvest managed to produce electrical voltages of few millivolts to hundreds of millivolts. The variables such as $\mathrm{pH}$, temperature, and moisture still need to be researched to make sure the harvesting operation is controllable. It is important to understand the concept used to scavenge the bio-energy from yeast as a step towards the practical application of this wasted energy.

\section{ACKNOWLEDGEMENTS}

The author gratefully acknowledges financial support from the Research Management Centre, UTHM under Grant U957.

\section{REFERENCES}

[1] S. Cauvain, "Technology of Breadmaking," Technol. Breadmaking, pp. 1-408, 2015.

[2] M. Heitmann, E. Zannini, C. Axel, and E. Arendt, "Correlation of Flavor Profile to Sensory Analysis of Bread Produced with Different Saccharomyces Cerevisiae Originating from the Baking and Beverage Industry," Cereal Chem., vol. 94, no. 4, pp. 746-751, 2017.

[3] M. Heitmann, E. Zannini, and E. Arendt, "Impact of Saccharomyces cerevisiaeMetabolites Produced during Fermentation on Bread Quality Parameters: A Review," Crit. Rev. Food Sci. Nutr., vol. 58, no. 7, pp. 1152-1164, 2018.

[4] M. Heitmann, C. Axel, E. Zannini, and E. K. Arendt, "Modulation of in Vitro Predicted Glycaemic Index of White Wheat Bread by Different Strains of Saccharomyces cerevisiae Originating from Various Beverage Applications," Eur. Food Res. Technol., vol. 243, no. 11, pp. 1877-1886, 2017.

[5] I. Borodina and J. Nielsen, "Advances in Metabolic Engineering of Yeast Saccharomyces cerevisiae for Production of Chemicals," Biotechnol. J., vol. 9, no. 5, pp. 609-620, 2014.

[6] G. Latremouille, "The Effect of Sucrose Concentration on the Percentage Change in Carbon Dioxide during Ethanol (Yeast) Fermentation," Essay, pp. 0-16, 2016.

[7] S. Wang, J. Yu, Q. Xin, S. Wang, and L. Copeland, "Effects of Starch Damage and Yeast Fermentation on Acrylamide Formation in Bread," Food Control, vol. 73, pp. 230-236, 2017.

[8] N. Struyf, E. Van der Maelen, S. Hemdane, J. Verspreet, K. J. Verstrepen, and C. M. Courtin, "Bread Dough and Baker's Yeast: An Uplifting Synergy," Compr. Rev. Food Sci. Food Saf., vol. 16, no. 5, pp. 850-867, 2017.

[9] F. N. Arroyo-López, S. Orlić, A. Querol, and E. Barrio, "Effects of Temperature, pH and Sugar Concentration on the Growth Parameters of Saccharomyces cerevisiae, S. kudriavzevii and their Interspecific Hybrid," Int. J. Food Microbiol., vol. 131, no. 2-3, pp. 120-127, 2009.

[10] A. Hagman and J. Piškur, "A Study on the Fundamental Mechanism and the Evolutionary Driving Forces Behind Aerobic Fermentation in Yeast," PLoS One, vol. 10, no. 1, pp. 1-24, 2015.

[11] Z. Cottle, C. Armstrong, E. Beckham, and A. Leone, "Sugar? Yeast Please!," J. Introd. Biol. Investig., vol. 7, no. 3, 2018.

[12] N. Hossain and R. Jalil, "Sugar and Bioethanol Production From Oil Palm Trunk (OPT )," Asia Pac. J. Energy Env., vol. 2, no. 2, pp. 81-84, 2015 
[13] H. Günan Yücel and Z. Aksu, "Ethanol Fermentation Characteristics of Pichia stipitisYeast from Sugar Beet Pulp Hydrolysate: Use of New Detoxification Methods," Fuel, vol. 158, pp. 793-799, 2015.

[14] J. Bauer, J. Burton, K. Christopher, B. Bauer, and R. Ritchie, "Ethanol Production in Yeast According to Sugar Type," J. Introd. Biol. Investig., vol. 5, no. 2, 2016.

[15] S. H. Mohd Azhar et al., "Yeasts in Sustainable Bioethanol Production: A Review," Biochem. Biophys. Reports, vol. 10, pp. 52-61, 2017.

[16] I. Y. Eom, J. H. Yu, C. D. Jung, and K. S. Hong, "Efficient Ethanol Production from Dried Oil Palm Trunk Treated by Hydrothermolysis and Subsequent Enzymatic Hydrolysis," Biotechnol. Biofuels, vol. 8, no. 1, pp. 1-11, 2015.

[17] F. Rodrigues, P. Ludovico, and C. Leão, "Sugar Metabolism in Yeasts: an Overview of Aerobic and Anaerobic Glucose Catabolism," Biodivers. Ecophysiol. Yeasts, pp. 101-121, 2006.

[18] M. Kim and D. F. Day, "Composition of Sugar Cane, Energy Cane, and Sweet Sorghum Suitable for Ethanol Production at Louisiana Sugar Mills," J. Ind. Microbiol. Biotechnol., vol. 38, no. 7, pp. 803-807, 2011.

[19] Q. Zhang, D. Wu, Y. Lin, X. Wang, H. Kong, and S. Tanaka, "Substrate and Product Inhibition on Yeast Performance in Ethanol Fermentation," Energy and Fuels, vol. 29, no. 2, pp. 1019-1027, 2015.

[20] H. C. Teng, B. C. Kok, C. Uttraphan, and M. H. Yee, "A Review on Energy Harvesting Potential from Living Plants: Future Energy Resource,” Int. J. Renew. Energy Res., vol. 8, no. 4, pp. 2598-2614, 2018.

[21] A. A. J. Jeman, N. M. S. Hannoon, N. Hidayat, M. M. H. Adam, I. Musirin, and V. Vijayakumar, "Experimental Study on Transient response of Fuel Cell," Bull. Electr. Eng. Informatics, vol. 8, no. 2, 2019.

[22] Z. Z. Ismail and A. J. Jaeel, "Modelling Study of an Upflow Microbial Fuel Cell Catalysed with Anaerobic Aged Sludge," Int. J. Ambient Energy, vol. 37, no. 1, pp. 85-93, 2016.

[23] W. L. Marques, V. Raghavendran, B. U. Stambuk, and A. K. Gombert, "Sucrose and Saccharomyces cerevisiae: A Relationship Most Sweet," FEMS Yeast Res., vol. 16, no. 1, pp. 1-16, 2015.

[24] K. Schmölzer, A. Gutmann, M. Diricks, T. Desmet, and B. Nidetzky, "Sucrose Synthase: A Unique Glycosyltransferase for Biocatalytic Glycosylation Process Development," Biotechnol. Adv., vol. 34, no. 2, pp. 88-111, 2016.

[25] J. Wess, M. Brinek, and E. Boles, "Improving Isobutanol Production with the Yeast Saccharomyces cerevisiae by Successively Blocking Competing Metabolic Pathways as Well as Ethanol and Glycerol Formation,” Biotechnol. Biofuels, vol. 12, no. 1, p. 173, 2019.

[26] H. Masumoto and S. Matsuyama, "The Combination of NAD+-Dependent Deacetylase Gene Deletion and the Interruption of Gluconeogenesis Causes Increased Glucose Metabolism in Budding Yeast," PLoS One, vol. 13, no. 3, pp. 1-13, 2018.

[27] P. R. Kidambi et al., "Nanoporous Atomically Thin Graphene Membranes for Desalting and Dialysis Applications," Adv. Mater., vol. 29, no. 33, pp. 1-8, 2017.

\section{BIOGRAPHIES OF AUTHORS}

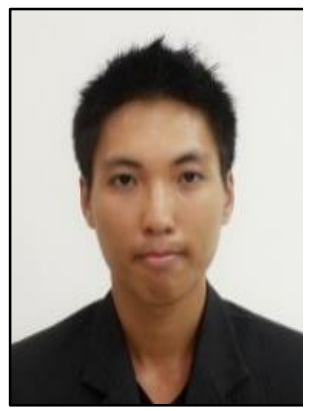

H. C. Teng is born in Kapit, Sarawak in Malaysia. He received his diploma of electrical engineering in 2012 from Kota Kinabalu Polytechnic, Sabah, Malaysia. He was awarded first class bachelor degree of electrical power engineering in 2017 from Universiti Tun Hussein Onn Malaysia, Johor, Malaysia. He is currently pursuing his Ph.D. degree in Universiti Tun Hussein Onn Malaysia, in the field of plant-microbial fuel cell.

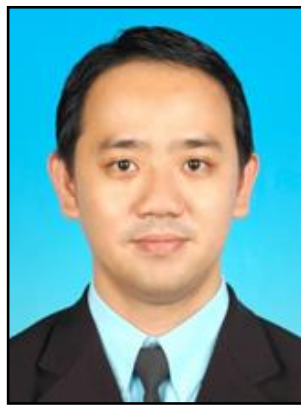

B. C. Kok obtained his B.Eng. (Electrical Engineering), M.Eng. (Power Systems) and Ph.D. (Power Systems) from Universiti Teknologi Malaysia (UTM) in 1998, 2001, and 2009, respectively. His technical interests are power system studies, energy savings and renewable energy analysis. He is currently serving Universiti Tun Hussein Onn Malaysia (UTHM) as Associate Professor in the Department of Electrical Power Engineering, Faculty of Electrical and Electronic Engineering since 2016. 


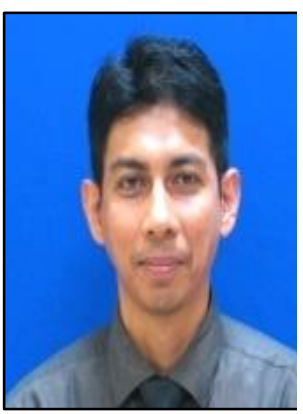

C. Uttraphan obtained his bachelor degree of electrical engineering in 2002, master of electrical engineering in 2004 from Kolej Universiti Tun Hussein Onn Malaysia and Ph.D. degree of electrical engineering in 2016 from Universiti Teknologi Malaysia, Johor, Malaysia. His field of expertise is in IC design. He is currently a senior lecturer in Universiti Tun Hussein Onn Malaysia.

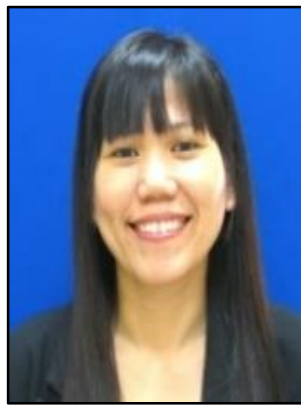

M. H. Yee obtained her bachelor degree of technology and education in 2002, master of technical and vocational in 2004 and Ph.D. degree of technic and vocational education in 2015 from Universiti Teknologi Malaysia, Johor, Malaysia. Her field of expertise is in higher order thinking skill (HOTS), learning and thinking styles and life-long education. She is currently a senior lecturer in Universiti Tun Hussein Onn Malaysia. 